\title{
THE BRITISH GLACIOLOGICAL SOCIETY (Reprint of a leaflet issued by the Society)
}

SNow and ice from their mutations and from the part they play in nature as precipitation, agents of erosion and modifiers of climate come within the range severally of physics, meteorology, geology, physical geography, oceanography and climatology. The behaviour of ice crystals in glaciers has close connection with crystallography and metallurgy.

On the more practical side, the study of the snow crystal has led to advances in the avoidance or prevention of avalanches and is therefore of value to railway engineers, mountaineers and ski-runners. Investigations on the freezing up of rivers and on the effects of snow cover upon "run-off" and floods have been actively taken up by water engineers and surveyors. In addition, the fascination of snow and ice and the beauty of the snowscape make wide appeal to laymen and many wish to know more about the subject.

It will be seen that these studies cover so wide a field that a central organization to coordinate them and to advise on programmes of research and exploration became a necessity.

As a result the British Glaciological Society was formed in 1936 as the "Association for the Study of Snow and Ice" whose primary object was "to encourage research on, and stimulate interest in, the practical and scientific problems of snow and ice." Since then the Society has broadened its activities. For example, it is the responsible body for nominating members of the British Group of the International Commission of Snow and Glaciers, one of the commissions of the International Association of Hydrology in the International Union of Geodesy and Geophysics. The Society is also resuming its annual Survey of Snowfall in the British Isles.

Meetings are held at about three-monthly intervals in London, Cambridge and other places, and the papers with their discussions are printed and circulated in the Society's Journal, which among other features will contain a useful glaciological bibliography.

Membership of the Society is open to all who have scientific, practical or general interest in any aspect of snow and ice study, and is by nomination. A proposer and seconder are not necessary. Further particulars may be obtained from the Assistant Secretary, British Glaciological Society, c/o Royal Geographical Society, Kensington Gore, London, S.W.7.

\section{THE TRANSACTIONS OF THE FORMER “ASSOCIATION FOR THE STUDY OF SNOW AND I CE"}

IT may be of interest at this stage to recall the papers and discussions at meetings since the commencement of the activities of the Association for the Study of Snow and Ice until the war put a temporary end to them.

\section{Date}

Dec. 111936
Venue

Royal Geographical Society, London
Paper

I. Survey of Snowfall in the British Isles and problems needing investigation in the Scottish Snowbeds
Read by

Mr. L. C. W. Bonacina 
Date

Dec. II 1936

Apr. $23 \quad 1937$

Royal Geographical Society, London

June 291937 Royal Geographical Society, London

Oct. 221937 Edinburgh

Oct. 261937 Royal Geographical Society, London

Dec. I6 I937 Royal Geographical Society, London

Apr. 61938 Joint with Association of British Members of the Swiss Alpine Club, London

Oct. 281938 Geographical Department, Cambridge

Dec. 8 1938 Royal Geographical Society, London

Apr. 21 $1939 \begin{gathered}\text { Geographical De- } \\ \text { partment, Cam- } \\ \text { bridge }\end{gathered}$
.

July 12 I939 Royal Geographical Society, London
Paper

Read by

2. Notes on the Snowfall in northern England.

3. The Firn Structure of the NorthEast Land Ice Cap

r. Ice and Snow (Névé): their erosional effects, with special reference to North-East Greenland

2. The Long-distance Mass Drifting of Snow in relation to the meaning of the Fall of Snow

I. Discussion on the inauguration of a system of snow reporting for the British Snowbeds

2. Discussion on the proposed Jungfraujoch Research Expedition

Discussion on the proposed reporting system for the British Snowbeds

I. Ditto

2. The possible application to snow of experiments on Drifting Sand

3. The share taken by Glacial and Fluvial Erosion in the Sculpture of Mountain Forms

The Structure and Flow of Glacier Ice

1. Snow and Ice Forms encountered by the ski-runner and mountaineer

2. Mountain weather and simple forecasting for the climber in Great Britain

I. Relic Glacial Forms in Graham Land

2. Sea-ice Problems in North-East Greenland and the Canadian Arctic

I. Nivation in the South Downs. Part I-Coombe Formation

2. Freeze-thaw processes in Cirque Sculpture

Results of the Jungfraujoch Research Party's Investigations

I. Report on the Snow Survey of the British Hills $1938-39$

2. Nivation in the South Downs. Part II-Formation of Dry Valleys
Mr. G. Manley

Mr. R. Moss

Dr. N. E. Odell

Mr. L. C. W. Bonacina

Opened by Mr.L.C.W. Bonacina

Opened by Mr. G. Seligman

Major R. A. Bagnold

Dr. R. B. McConnell

Dr. L. Hawkes

Mr. A. D. Baines

Mr. G. Manley

The Reverend W. L. S. Fleming

Mr. J. M. Wordie

Dr. A. J. Bull

Mr. W. V. Lewis

Members of the party

Mr. G. Manley

Dr. A. J. Bull 
Date

July 121939 Royal Geographical Society, London

Feb. 7 1940 Geological Society, London
Paper

3. Discussion to make proposals for Admiral Byrd's Antarctic Expedition

I. Preliminary report of the International Union of Geodesy and Geophysics, Washington Congress, 1939

2. Report on the Snow Survey of the British Hills 1939-40
Read by

Opened by the Reverend W. L.S. Fleming

Dr. N. E. Odell

Mr. L. C. W. Bonacina

The transactions at the meeting of 12 July 1939 are summarized in Papers and Discussions, Vol. I (3), which is available free to members and at $2 s .6 d$. for non-members. There are a few numbers of Vol. I (2) summarizing the transactions of 21 April 1939, price 2s. 6 d. each to members and 5 s. to non-members. The remaining transactions are recorded in the Minute Book and typed copies can be supplied by special arrangement.

\section{MEETINGS}

\section{GENERAL MEETING}

held at the Royal Geographical Society's House, Kensington Gore, London, on Monday, 22 October 1945

22 members and 3 visitors were present

I. President's Report. The President (Mr. G. Seligman) welcomed members after the long lapse of years. He reminded them that the last meeting had taken place on 7 February I $94^{\circ}$ and gave a brief summary of that meeting, the matter most important to those now present being the report of the amalgamation of the two International Commissions of Snow and of Glaciers into one body at the Geophysical Congress at Washington in September 1939. In elaborating the report made at that time, the President said that there would be a permanent Committee of Glacier Measurement within the new Commission in order that this work could be carried on uninterruptedly.

Passing to the present day, the President said that before long the next meeting of the International Union of Geodesy and Geophysics would be arranged and that it would probably take place in one of the Scandinavian countries or Switzerland.

It was hoped soon to approach members of the British Groups of the old Commissions of Snow and of Glaciers to see if they were willing to continue, and it had been suggested that Mr. J. M. Wordie and he should jointly head the British Group.

Referring to the United States Antarctic Service Expedition of 1939-4I, the President said that he had just received a gratifying acknowledgement from Professor J. Alton Wade, the expedition's senior scientist, of the research programme which the Association had prepared for him and on which the expedition's final plans had been based. The preliminary paper on the results had now arrived, together with some lantern slides, and would be presented by the Reverend W. L. S. Fleming during the summer of 1946.

At the meeting of February 1940, another meeting had been fixed for May of that year in Oxford, but it had had to be cancelled and the work of the Association had then lapsed 